\title{
A MULTI-LEVEL STUDY ON FRANCHISEE- AND SYSTEM-LEVEL ANTECEDENTS OF OPPORTUNISM AND SATISFACTION
}

\author{
Heiner Evanschitzky, Aston University, UK \\ Barbara Caemmerer, ESSCA, France \\ Christian Brock, Zeppelin University, Germany
}

\begin{abstract}
Franchising as a business model has gained increased economic importance and research attention over the last three decades. While prominent in many industries, franchising is now particularly common in sectors where production and consumption has to take place simultaneously, and which need to operate through diffused distribution networks with outlets that are located close to customers and managed by individuals with local knowledge. It is for this reason that the success of such operations strongly depends on the proper selection of franchisees, as well as the implementation of practices to manage the relationship with franchisees. Therefore, the majority of authors in this field of research have based their studies on transaction cost economics (TCE) reasoning, which recognizes the importance of safeguarding against adverse selection and opportunistic behavior (moral hazard) in economic partnerships.
\end{abstract}

While a lot of research has focused on the investigation of contractual arrangements in order to protect franchisors from franchisee opportunism, less attention has been paid to the problem of adverse selection. In particular, the relationship between franchisee characteristics, franchise system characteristics and practices, and franchisee opportunism and satisfaction have not been considered suficiently. Therefore, to contribute to the extant literature, we apply the Theory of Planned Behavior (TPB) to the franchising context. Departing from the assumption of TCE that individuals are rational actors who will always behave opportunistically, we investigate across different franchise systems how franchisee attitudes towards business are linked to opportunism and satisfaction, as well as how these links are moderated by characteristics and practices constituting the franchise system.

While opportunism is a well-established concept in the franchise literature, franchisee satisfaction with their business decision has received less attention as a desired outcome variable for franchisors. However, there is reason to suggest that franchisee satisfaction is important for the success of the franchise system for two reasons: 1) There is evidence that dissatisfaction of channel members is related to their exit intentions, which means that transaction specific assets (TSA) may be lost. 2) Dissatisfaction is also related to negative word-of-mouth, which can lead to a negative reputation, which in turn is associated with higher transaction costs when trying to enter new contracts.

In light of the above and based on prior empirical research on franchisee selection, we focus our investigation on five franchisee attitudes towards business (ATB) which are commonly discussed in the literature. These are: 1) perceived innovativeness, 2) business risk-taking; 3) seek work-related challenges, 4) desire for personal development, and 5) commitment to the business. While there is some evidence that entrepreneurial personalities are prone to these attitudes, less is known about how these attitudes are linked to levels of opportunism and satisfaction in the context of a franchise system.

The few studies that have explored the link between franchisee attitudes on franchisor outcomes have considered these relationships in isolation. However, TPB research suggests that the link between attitudes and behavior is moderated by a person's beliefs as to whether it is easy or difficult to perform an act. These perceptions of control depend on past experiences as well as current obstacles to, or opportunities for, the performance of a behavior. Applied to the franchise context, we argue that franchise system characteristics and practices moderate the link between ATB, opportunism and satisfaction. We use type of contracting and franchisors' investment of TSA into franchsees' outlets as examples of system characteristics and practices to test our hypotheses.

The results of hierarchical linear models (HLM) give an indication on what attitudinal bases potential franchisees may be selected prior to signing a long-term franchise contract to avoid adverse selection and opportunism. Particularly, it seems that seeking challenges and risk taking are associated with high levels of opportunism, whereas seeking personal development and commitment reduce opportunism. Interestingly, franchisee satisfaction seems to be primarily driven by the same two variables that increase opportunism. Further, the findings reveal how type of contracting and franchisors' TSA investment impact on franchisee behavior and attitudes ex-post.

References Available on Request. 